\title{
Analysis of the Mechanism of Ideological and Political Promotion in the Construction of Red Culture in Shaanxi Province
}

\author{
Hu Hong \\ Xi'an Peihua University, Shaanxi, China, 710077
}

Keywords: Shaanxi; red culture; colleges and universities; campus culture; role

Abstract: Shaanxi red culture plays an important role in the historical process of the Chinese revolution. It is the passing of the Chinese national spirit in the revolutionary war years and the concentrated expression of the fine tradition of our party. Under the background of striving to realize the "Chinese Dream", the campus culture construction of colleges and universities is facing a new round of opportunities and challenges. Therefore, this paper analyzes the current situation of campus culture construction in colleges and universities, deeply explores the role of Shaanxi red cultural resources in the construction of campus culture, and explores the countermeasures of using Shaanxi red cultural resources to create college red campus culture. This plays an important role in promoting the national spirit, promoting the early realization of the "Chinese Dream" and promoting the growth of contemporary college students.

\section{Introduction}

Colleges and universities are not only the place to teach scientific and cultural knowledge and cultivate talents, but also the main carrier for cultivating college students' ideological and moral. Strengthening the construction of campus culture and forming a good campus culture atmosphere can help students establish a correct world outlook, outlook on life and values. Especially in the red land of Shaanxi, the effect is particularly outstanding. Therefore, in-depth exploration of the intrinsic value of Shaanxi's red cultural resources and its application to the campus culture construction of colleges and universities can not only carry forward the inheritance of the great revolutionary spirit, but also create a good red campus atmosphere and contribute to the comprehensive quality of young college students. Cultivate, point out the direction of struggle for the majority of young students, and guide them to make unremitting efforts to realize the "Chinese Dream."

\section{Problems in the construction of college campus culture under the new situation}

\subsection{The construction of campus culture is not conducive to the cultivation of students' comprehensive quality}

It is one of the tasks of college education to cultivate talents suitable for social needs. Therefore, 
college education is not only to impart scientific and cultural knowledge to students, but also to the cultivation of students' talents. However, most colleges and universities do not recognize the importance of this work when constructing campus culture. The simple understanding is to enrich students' after-school life and ease the intense study of students. This work is summarized into some cultural and sports activities. Entertainment activities, etc. The enthusiasm and participation of students, the students did not form a correct understanding, to a certain extent is not conducive to the cultivation of students' comprehensive quality, it is difficult to form a good character. In the absence of a good campus culture environment, students often lose their way, so it is difficult to achieve the effects and goals of "cultural education" in college education[1].

\subsection{Campus culture construction is not conducive to the individualized development of students}

For different types of colleges and universities, there are certain differences in terms of school orientation and talent training programs. Therefore, there are differences in the school-running thinking and school-running characteristics. The campus culture needs of different universities are also different. At the same time, colleges and universities did not carry out some cultural activities with artistic, ideological and high-level elegance, and did not reflect their own cultural characteristics, so they could not achieve the purpose of inheriting the fine cultural traditions of colleges and universities. For the majority of young students, because the school's campus cultural activities lack creativity, the content is boring, can not fully mobilize the enthusiasm and creativity of learning, so that teachers and students lack good and effective communication and communication. Lack of exercise in actual campus cultural activities, can not dig deep into the free nature of students' independent thinking, students can not improve their cultural literacy without accumulating rich knowledge[2].The correct mode of red cultural education is as follows.

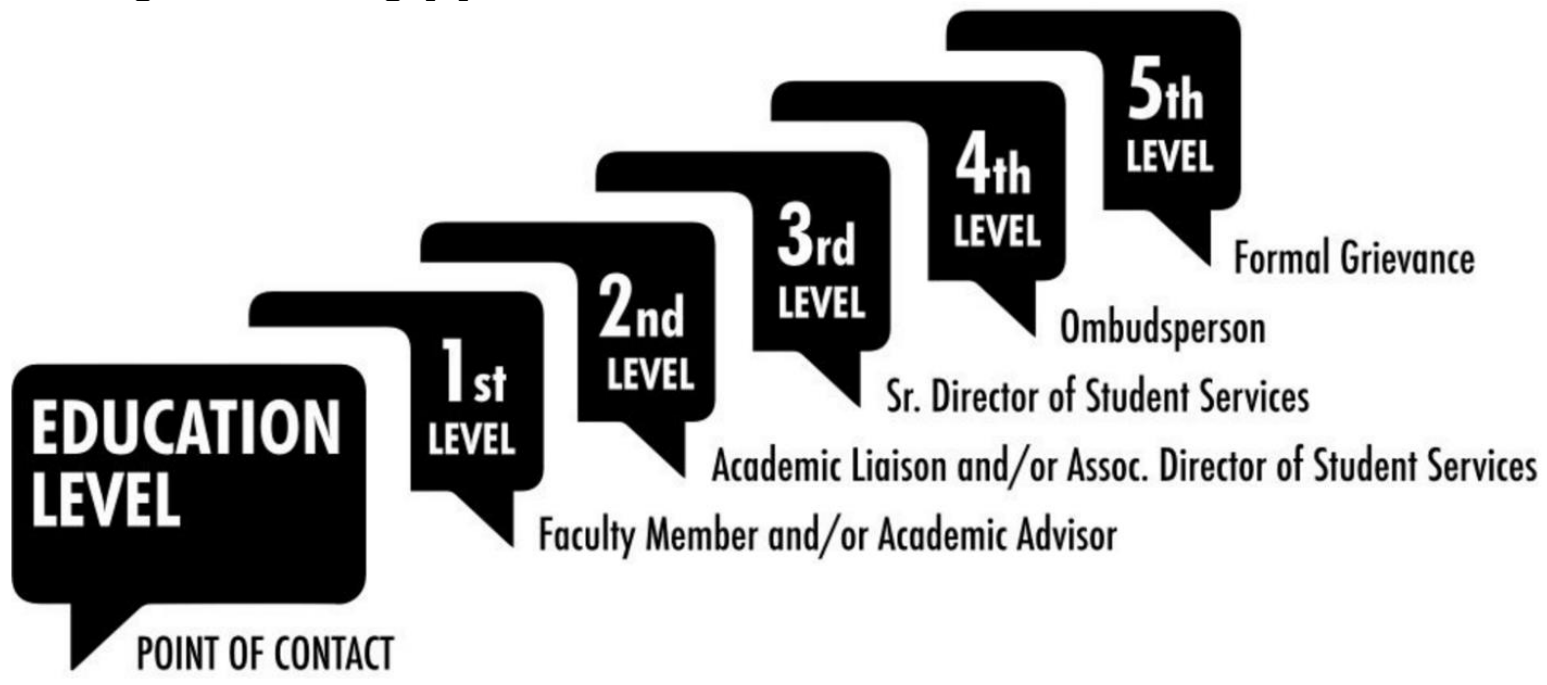

Fig.1 Correct mode of red cultural education

\subsection{Campus culture construction is not conducive to the realization of cultural construction goals}

With the continuous development of the economy, the rapid development of science and technology has provided material security for the development of contemporary education. To a certain extent, it plays an important role in enhancing the power of running a university and improving the level of running a university. Therefore, for the university, in the new era, in order to 
keep up with the pace of the times, we have increased the investment in the construction of the material culture of the campus, and put the so-called "face" projects such as the expansion of campus roads and the construction of campus buildings into construction. The focus, while ignoring the construction of campus spiritual culture, has led to the irrationality of the campus culture development structure to a certain extent, which has caused serious harm to the sustainable development of the school. In the new era, although all colleges and universities have accelerated the pace of campus culture construction, due to the lack of correct theoretical guidance and the inconsistency between campus material construction and spiritual culture construction, it has not created a good campus culture atmosphere. The students form the values of material first and second thought, and do not pay attention to the improvement of spiritual culture, which affects the cultivation of high-quality talents in colleges and universities in a certain degree[3].

\section{The role of Shaanxi red cultural resources in the construction of college campus culture}

\subsection{Use Red Culture to Guide College Students to Establish Correct Life Values}

With the continuous development of society, various ideological trends have emerged, which have affected college students to form a correct world outlook, outlook on life and the formation of values. Therefore, when colleges and universities are building campus culture, they must learn to use Shaanxi red cultural resources to guide college students, usually including the following two aspects. First of all, establish a sense of quality. Due to the lack of correct understanding of red cultural resources, contemporary college students often ignore the importance of red cultural resources. Therefore, when carrying out campus culture construction, colleges and universities should implement a boutique strategy to build Shaanxi red cultural resources into a boutique with advanced culture and high aesthetic requirements, and provide more cultural services and cultural products for contemporary college students. Then, Create cultural boutiques. Shaanxi's red cultural resources are rich in content. On the one hand, it includes the fierce struggle in the revolutionary war years, and on the other hand, it includes deep emotional comradeship and friendship. In the process of innovation, we must not only start from the content of Shaanxi red cultural resources, but also realize the innovation of communication carriers. Only by combining the forms and contents well can we truly enter the hearts of contemporary college students[4].Red education investment in various places as shown below.

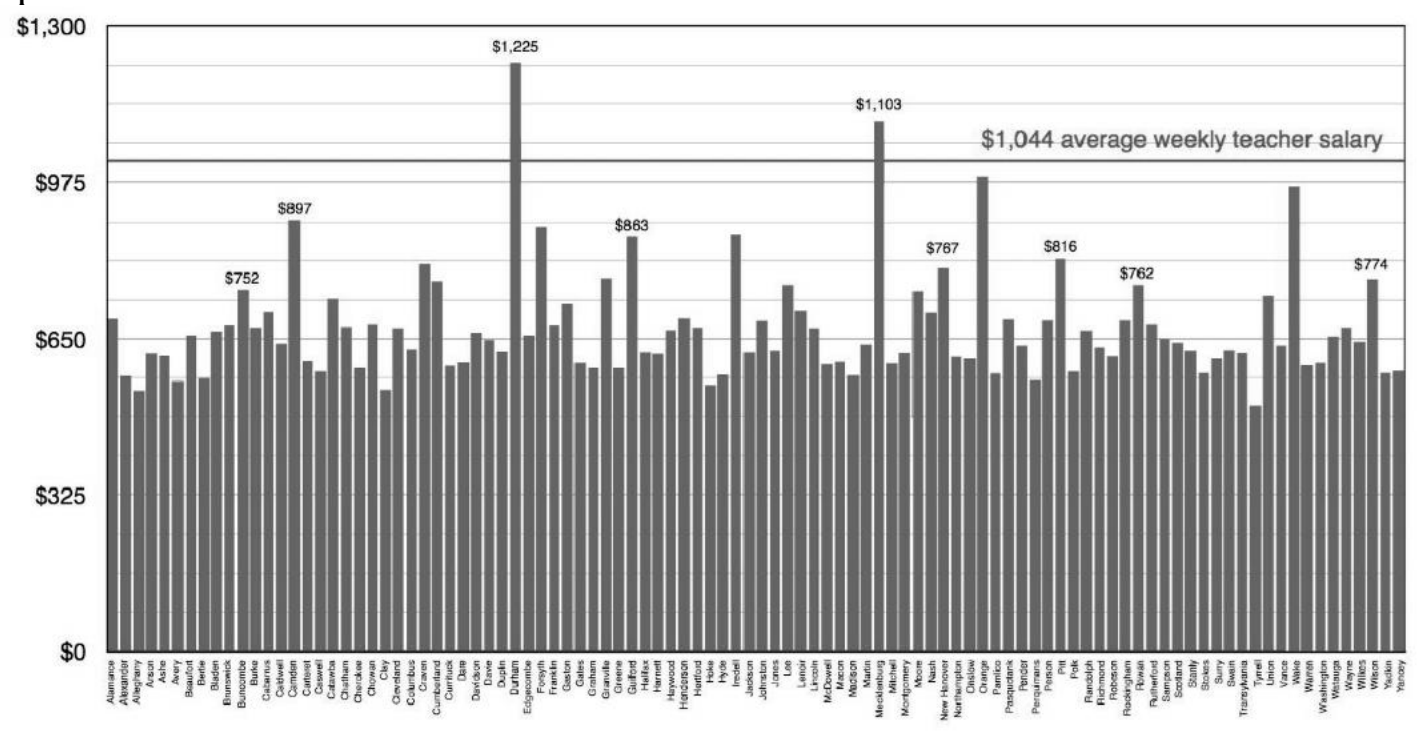

Fig.2 Red education investment in various places 


\subsection{Combine red culture with classroom content}

For college students, the classroom is the most important place to learn, and it is the place that can influence the growth of students. The "Red Classic" has nurtured the growth of a generation. These red classic works have played a positive role in inheriting the Chinese national culture to a certain extent and have unique educational value. Therefore, when carrying out campus culture construction, colleges and universities can integrate Shaanxi red cultural resources into ideological and political education, and then cultivate students in a targeted manner. This not only allows students to learn relevant classroom knowledge, but also understands the essence of Shaanxi red culture in a subtle way. For example, when the teacher is in the ideological and political education class, he can combine the boring theoretical knowledge with the heroic struggle stories of the martyrs in the revolutionary period. This can not only effectively improve the efficiency of classroom teaching, but also to a certain extent, the young college students can get close to the red culture of Shaanxi, understand the connotation of Shaanxi red culture, and experience the spirit of struggle of revolutionary martyrs.

\subsection{Integrating red culture with network construction}

With the continuous development of the economy, computer Internet technology has also developed rapidly. For the majority of young students, the network culture affects students' values and ideology to some extent. Therefore, when carrying out campus culture construction, colleges and universities should give full play to the role of the network, and carry out ideological and political education based on Shaanxi red culture through the network. Judging from the current situation of campus culture construction in China's colleges and universities, most colleges and universities have established campus culture websites based on ideological and political education. However, because the website is mainly composed of large texts, it is too boring and can not arouse students' Click on interest. Therefore, colleges and universities can integrate red culture with website construction when constructing campus culture. When designing websites, the students' actual needs and interests are taken as the basic premise, and students are more interested in forms, such as red cultural knowledge. PK platform, animation contests based on red stories, etc., allow students to discover the fun of campus culture websites, and focus on the campus culture website. While actively participating in various interesting activities, they can learn more. More knowledge about Shaanxi's red culture, enriching its knowledge reserves, improving cultural literacy, and thus growing into a comprehensive talent that meets social needs.

\section{Summary}

With the rapid development of China's economy, the government pays more and more attention to the construction of spiritual civilization. The construction of university campus culture is an important part of spiritual civilization construction. For colleges and universities, in the process of building campus culture, we must deeply interpret the red culture of Shaanxi. In particular, the leaders of colleges and universities should have a deep understanding of the concepts related to red culture. Only in this way can we make correct decisions. In the process of fully applying Shaanxi red culture to the construction of campus culture, colleges and universities should create a good campus culture atmosphere, help students establish firm ideals and beliefs, establish a correct world outlook, values and outlook on life, and contribute to the "Chinese Dream" at an early date. A force of your own. 


\section{References}

[1] Nadeen El-Kassem. The pitfalls of a 'democracy promotion' project for women of Iraq[J]. International Journal of Lifelong Education,2008,27(2).

[2] Michael J Boyle. Between freedom and fear: Explaining the consensus on terrorism and democracy in US foreign policy[J]. International Politics,2011,48(2-3).

[3] Weiren Yuan, Yaqing Zeng. Study of Methods to Improve the Counselors' Scientific Research[J]. Creative Education,2017,08(03).

[4] Yi Hui Pan,Guang Qing Wang,Juan Juan Qin,Ke Qin Tu. Research on the Mode of Ideological and Political Communication[J]. Advanced Materials Research,2014,3181(926). 